\title{
THE UNIVERSAL HYDRAULIC STRUCTURE
}

\section{Rogachko S. I., Slobodianyk H. V.}

\section{INTRODUCTION}

The total length of sea and river coasts is measured in thousands of kilometers in Ukraine. It so happened historically that many of them have a lot of settlements, from small villages to large cities. The force action of the aquatic environment in the form of wind waves, currents and drifting ice formations on the coast has always been destructive, especially with sharp increases in water levels. For this reason, the protection of the shores of lakes, rivers, reservoirs and seas in our country is an actual technical problem.

The construction of any kind of structures in the immediate vicinity of the water is a direct intervention in nature, which causes various problems. So the availability of a private sector, located on the coast, is associated with intensive watering of plants and trees in personal plots, especially in the southern regions of the country. Due to the difference between the marks of such territories and the water level in water bodies, irrigation water, along with a part of the atmospheric precipitation, saturates the coastal slopes, changing the physical and mechanical characteristics of the soils from which they are composed. Torrential streams of water flush out fine particles of the surface soil layer and also cause erosion of the steep parts of the coastal slopes. The part of the fine-grained soil layers facing water bodies, which is not protected by vegetation, is partially exposed to wind erosion. Thus, the process of coastal destruction occurs constantly on both sides of the water edge.

It is possible to resist the destruction of the shores of water bodies in order to preserve previously constructed, both single objects and settlements, with the help of a number of special technical activities. The simplest ones include the removal of torrential streams and ground waters, saturating coastal slopes. The more expensive measures include the construction of coastal protection structures that would stop the advance of various types of water bodies on the coast. The destruction of coasts can be avoided by the construction of coastal protection structures and new types. Such designs can successfully withstand the forceful effects of natural factors. In addition, they are also applicable for the creation of artificial territories during the onset of land towards water areas.

Marine coastal protection structures built in Ukraine more than 30 years ago are either in emergency or in a completely destroyed state. The reasons for such damage, established on the basis of the analysis of the results of field surveys, are quite enough. The most significant of them is the unsatisfactory quality of work in the process of their construction. This primarily relates to the quality of concrete and the technology of manufacturing structural 
elements at factories of reinforced concrete products, as well as to the device of the stone base and installation of the main structural elements of shore protection structures on it.

\section{INNOVATIVE SHORE PROTECTION STRUCTURE}

An innovative constructive solution of a shore protection structure is presented in this paper. This solution is protected by a patent of Ukraine for a utility $\operatorname{model}^{1}$ (Fig. 1, a).

The shore protection structure consists of vertical piles 1, arranged along a certain step in length, supporting frames 2 , which are installed on a stone base 4 and are monolithic with piles 1 concrete 3 , face plates 5 with icebreaking half-pyramidal elements 6 , which are attached to the supporting frame 2, stone sketch 7, wave breaker wall 8 and backfill sand 9 .

This design can also be implemented with vertical slabs (Fig. 1, b) when used as coastal protection structures or shallow promenades in cramped urban conditions.

In ice-free periods, faceplates will perceive wave loads during storms. In this case, inclined faceplates will reduce the height of the storm waves. Icebreaking semi-pyramidal elements of an intermittent type, located on the front surface of the plates with a certain step, also contribute to the dissipation of the wave energy ${ }^{2,3}$. Due to the shape of the wave-breaking wall, wave bursts will be thrown towards the sea, thereby preventing the formation of spray icing in the protected area at negative air temperatures.

During the winter periods, under the force of the action of level ice, their destruction will occur, thanks to the ice-breaking semi-pyramidal structural elements of discontinuous type, in two mutually perpendicular planes. Icedestroying elements will contribute to the occurrence of stress concentrations at the points of contact with level ice, causing cracks, crumpling and crushing of ice, as well as a decrease in its local pressure. Level ice fields will be destroyed due to the bending of the ice during their creep onto the inclined surface of the wall. In this case, a buffer zone will be formed in front of the structures from the debris of level ice. All this helps to reduce the global ice load on the structure. The wave-breaking wall of the curved profile will also prevent ice debris from creeping into the protected area.

1 Patent na korisnu model' № 113315. Ukraïna. MPK(2006.01) E02B 3/04. Beregozahisna sporuda / Rogachko S. I., Slobodyanik G.V.; vinahidniki ta vlasniki Rogachko S.I., Slobodyanik G.V.; zajavl. 29.06.2016; opubl. 25.01.2017, Bjul. № 2. 4 s.

2 Patent na korisnu model' № 42602, Ukraïna. MPK (2009) E02V 3/00. Universal'na beregozahisna sporuda / Rogachko S.I., Anisimov K.I, Sinicja R.V.; vlasnik Rogachko S.I. u200901751; zajavl. 27.02.2009; opubl. 10.07.2009, Bjul. № 13. 6 s.

3 Patent na vinahid № 92099, Ukraïna. MPK (2009) E02V 3/04, E02V 3/06. Universal'na beregozahisna sporuda / Rogachko S.I., Anisimov K.I, Sinicja R.V.; vlasnik Rogachko S.I. a200901752; zajavl. 27.02.2009; opubl. 27.09.2010, Bjul. № 18. 6 s. 


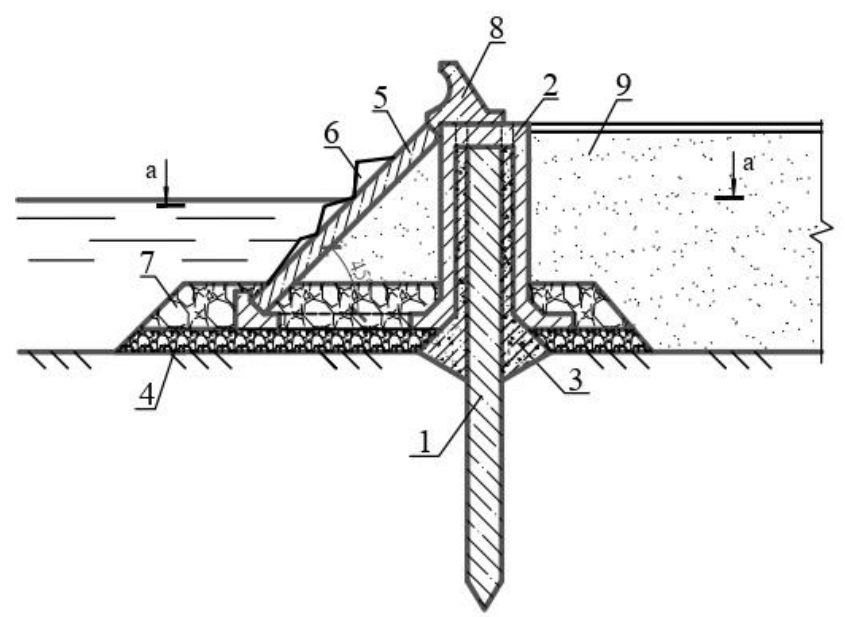

a)

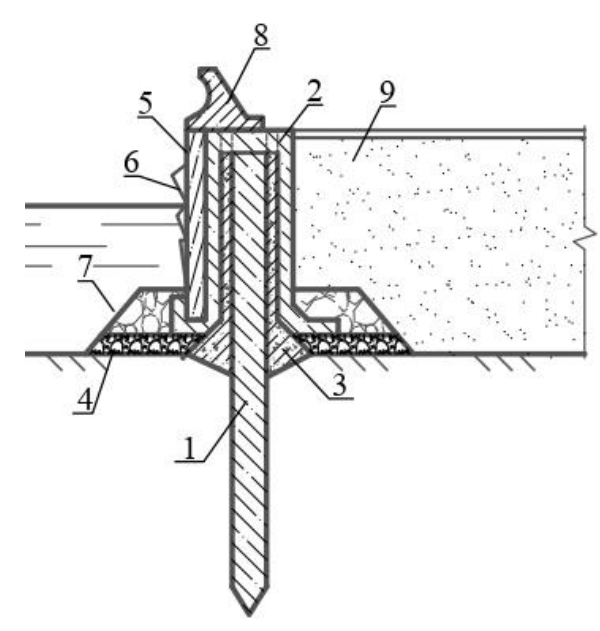

b)

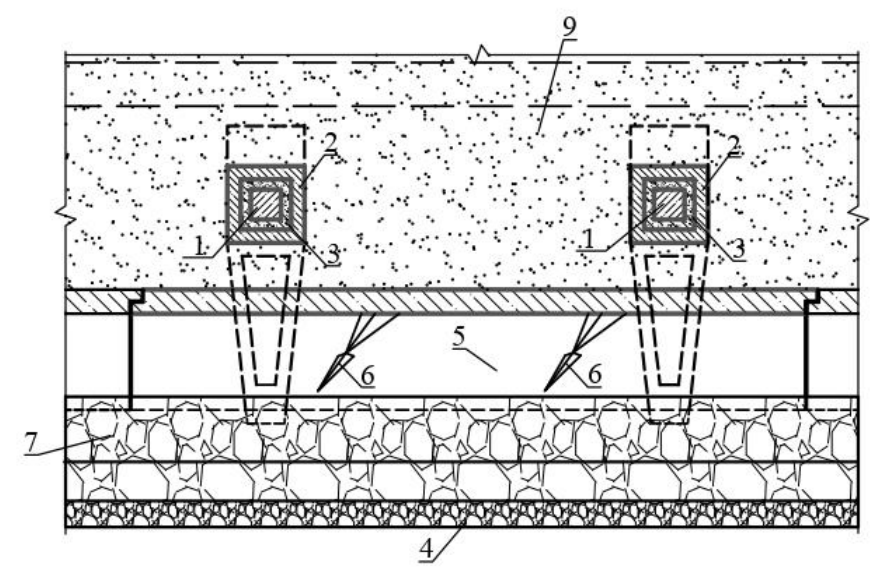

c)

Fig. 1. Shore protection structure: $a$ - with an inclined face plate; b - with a vertical face plate; $c$ - section a-a

A stone banquet will prevent erosion of the foundation soil at the structure by currents and wind waves, and with the vertical arrangement of the slab and from the operation of ship propellers. In addition, a stone banquet will protect frames, faceplates and piles from abrasion by sediments. The bottom layer of the stone banquet is a counter filter to prevent the washing out of small particles of backfill soil.

This universal hydraulic engineering structure can also be successfully used when attacking water bodies in order to form new additional territories adjacent to land, including artificial islands for various purposes. For example, in the development of offshore hydrocarbon deposits in shallow areas of the continental shelf. The use of rabble stone and sand in this design will significantly reduce the cost of structures in those regions where these building materials are local rather than imported. 


\section{ACCOUNTING FOR EXTERNAL LOADS}

This coastal protection structure (or artificial island) must be counted on forcing by wind waves and level ice in severe winters of rare frequency, as well as on seismic loads.

All scenarios for calculating wave loads for the structure under consideration are, in principle, contained in the recommendations of the regulatory document SNiP 2.04.06-82*4, taking into account its location in different zones of passage of wind waves to the shore (Fig. 2, 3). Nevertheless, it is advisable to refine the values of wave loads experimentally in the process of scientific support of a specific project. Such an approach will allow to take into account the whole variety of design features of this structure and to obtain the exact value of the wave load, as well as the wave situation before the structure during the design storm. Moreover, taking into account the topography of the bottom of the designed structure and the calculated parameters of the wind waves will provide a sufficiently high accuracy of the results of experiments.

Since all shore protection structures are built in shallow areas, they are only exposed to level ice in winter periods. The calculated values of ice loads from level ice on structures with a vertical front face, without taking into account structural ice-breaking elements, can be determined in accordance with the recommendations of the same norms ${ }^{4}$ in two design scenarios. As it is known, one of them takes into account an impact from drifting level ice at a certain speed of the calculated size, thickness and strength (Fig. 4, a), and the other is its destruction by crumpling and crushing before construction (see Fig. 4, b).

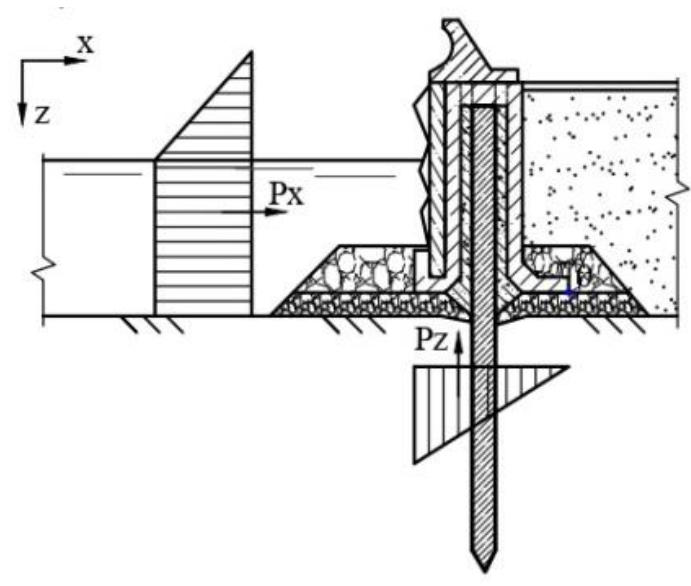

a)

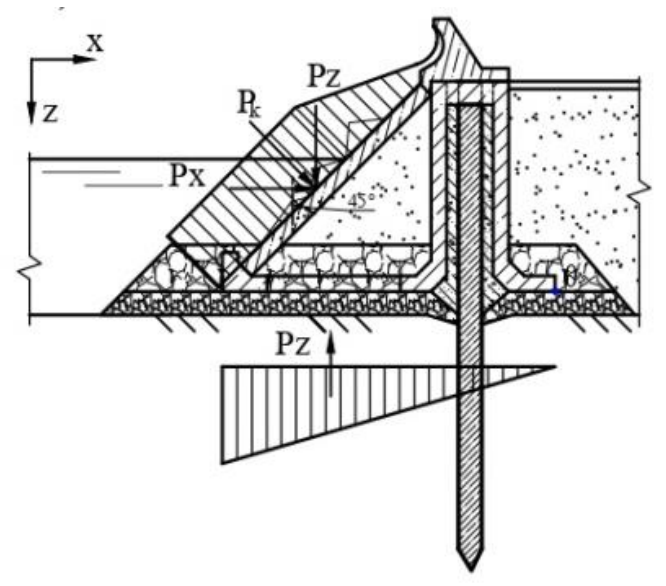

b)

Fig. 2. Plots of wave pressure on the wall from breaking waves: a - plot of wave pressure on a vertical wall; b - plot of wave pressure on an inclined wall

4 SNiP 2.06.04-82*. Nagruzki i vozdejstvija na gidrotehnicheskie sooruzhenija (volnovye, ledovye i ot sudov). Vzamen SNiP II-57-75: vved. 01-01-1984. M., 1995. 76 s. 


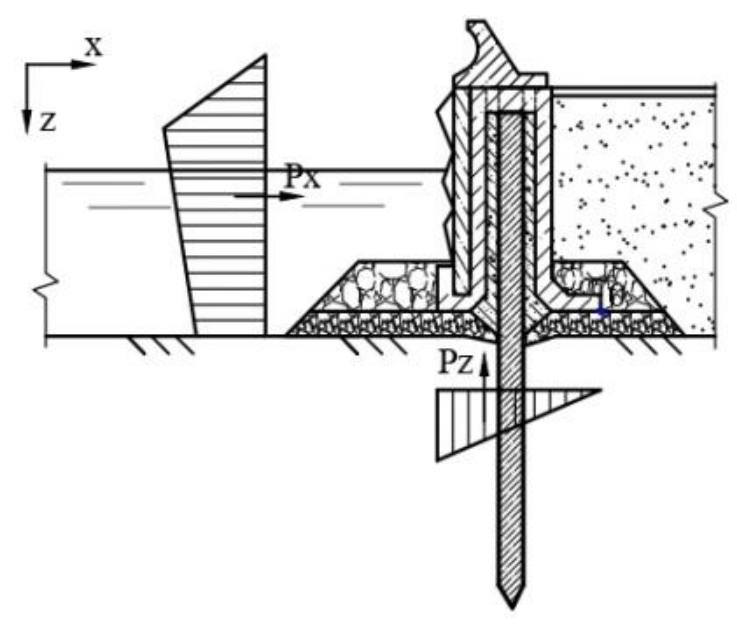

a)

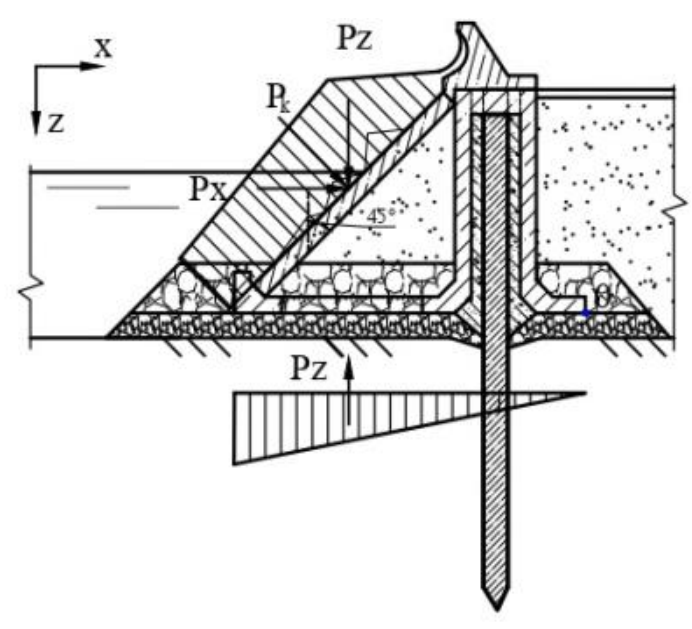

b)

Fig. 3. Plots of wave pressure on the wall from breaking waves:

$a$ - plot of wave pressure on a vertical wall; $b$ - plot of wave pressure on an inclined wall

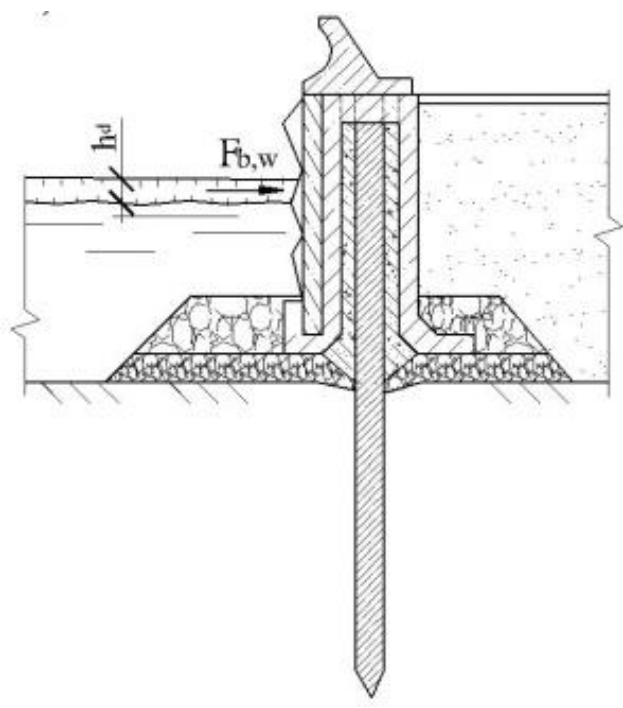

a)

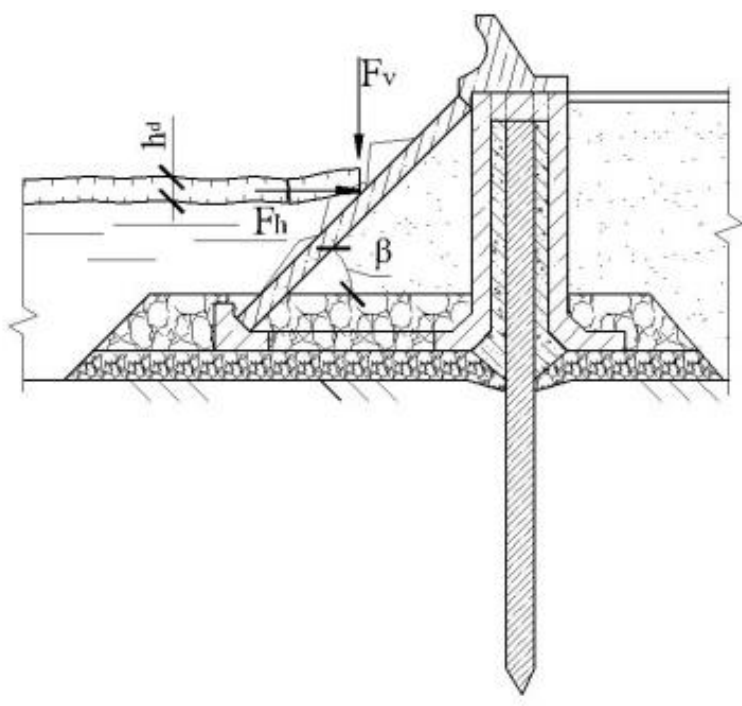

b)

Fig. 4. Schemes of action drifting level ice: $a$-ice load on the vertical wall; $b$ - ice load on the inclined wall

It should be noted that the ice load from the force impact of level ice fields on structures with an inclined front face will be significantly less than the load on structures of a vertical profile, since the bending strength of ice is used as a strength parameter in the calculated dependences in such cases. In addition, the ice load on structures with an inclined face is represented by horizontal and vertical components. Moreover, the vertical component contributes to the stability of structures. 
The presence of structural elements on the face of the structures will significantly affect the picture of the destruction of level ice, and therefore reduce the ice load, since the process of ice destruction will be accompanied by the appearance of ring and radial cracks in the zones of point contact of ice. A quantitative assessment of the reduction in ice load can only be detected experimentally with structurally modeled ice in the process of physical modeling at given values of negative temperatures in laboratory conditions.

In cases where this construction is used to create artificial islands when equipping offshore hydrocarbon deposits at moderate water depths, in addition to level ice, it is also necessary to take into account the force action of single hummocks and hummock fields. The sizes of design hummocks and ice loads from them can be determined in accordance with the recommendations of the departmental regulatory document ${ }^{5}$. The same standards also contain recommendations on the calculation of local pressures from level ice and hummock fields on structures of a vertical type. Local pressure is manifested at the initial moment of contact of ice formations with the supporting parts of structures in the zone of variable water level. It significantly exceeds the uniaxial compression strength of ice.

The account of loads during seismic actions on such structures must be carried out in accordance with the recommendations of DBN B.1.1-12:2014 and taking into account the engineering and geological conditions in the base.

External loads and weight will be transmitted to the soil through the piles, so this design is not very sensitive to base subsoil sediments and soil erosion. Such structures can be successfully used on weak eroded soils of the base.

In the process of designing such structures, it is necessary to calculate the elements of their structures:

- determination of the pilling depth ${ }^{7}$;

- calculation of piles for horizontal loads and moments, it must be taken into account that the cross section of piles above the bottom level is increased due to the size of the supporting frames and monolithic units ${ }^{7}$;

- calculation of front reinforced concrete slabs that perceive the force of wind waves and drifting ice formations based on four points ${ }^{8}$;

- calculation of ferroconcrete frames ${ }^{8}$;

${ }^{5}$ Ukazanija po raschetu nagruzok i vozdejstvij ot voln, sudov i l'da na morskie gidrotehnicheskie sooruzhenija. R 31.3.07-01, M., 2001. Dopolnenie i utochnenie SNiP 2.06.04-82* "Nagruzki i vozdejstvija na gidrotehnicheskie sooruzhenija (volnovye, ledovye i ot sudov), M., 1995, M., 2001. 77 s.

${ }^{6}$ DBN V.1.1-12:2014 "Budivnictvo v sejsmichnih rajonah Ukraïni”. K.: Minregionbud Ukraïni. Kiïv, 2014. $118 \mathrm{~s}$.

${ }^{7}$ DBN V.2.1-10:2018 “Osnovi i fundamenti budivel' ta sporud. Osnovni polozhennja”. Vved. na zminu DBN V.2.1-10-2009; chinni vid 2019-01-01. Kiïv: Minregionbud Ukraïni, 2018. $36 \mathrm{~s}$. 
- determination of the mass of stone, taking into account the extreme design parameters of wind waves in order to prevent erosion of soil at the base of the structure? .

All above enumerated calculations are classical and approved in engineering practice, including in hydraulic engineering construction.

\section{TECHNOLOGY FOR THE CONSTRUCTION OF A SHORE PROTECTION STRUCTURE}

The construction of all types of coastal protection structures is a very timeconsuming and complex technological process, taking into account the fact that they are being built in unprotected waters areas. In this paper, a method for constructing a universal marine hydraulic engineering structure is described (Fig. 1), in which a passive type shore protection structure is assembled from simple unified elements manufactured in the factory. This method is protected by the patent of Ukraine ${ }^{10}$.

The method of construction of universal hydraulic structures is as follows. The geodesy breakdown and fixation of the targets on the terrain are tied to a triangulation or polygon state network. Then ferroconcrete piles are immersed in the foundation soil with a certain step and the first stage of stone filling is poured under the design mark (see Fig. 5, 6). The heads of ferroconcrete piles are cut to the design elevation and support frames are installed on them (see Fig. 7). Piles and support frames are monolithic with concrete so that a part of the concrete mix reaches the bottom of the pile, forming an additional bottom emphasis (see Fig. 8).

After the solidified concrete has hardened, inclined or vertical faceplates are installed (see Fig. 9). Next, the second stage of the stone backfill is performed, forming a banquet, and the backfill (Fig. 10). Upon completion of the stone banquet, backfilling with sand or the formation of the territory is carried out (Fig. 12). At the same time, depending on the object under construction, either a motor vehicle or a marine dredger can be used.

Stacked sand must be thoroughly compacted. For this purpose, various compaction methods can be applied, which also depend on the structure of the building under construction. Having completed these works, in the surface part, a monolithic wave-breaking wall is installed on the concrete preparation layer (Fig. 11). Along the length of the structure, the wave breaker wall is divided into sections by temperature seams.

8 DBN V.2.6-98:2009 "Konstrukciï budinkiv i sporud. Betonni ta zalizobetonni konstrukciï. Osnovni polozhennja”. K.: Minregionbud Ukraïni. Kiïv, 2011. 71 s.

9 SNiP 2.06.04-82*. Nagruzki i vozdejstvija na gidrotehnicheskie sooruzhenija (volnovye, ledovye i ot sudov). M., 1995. $76 \mathrm{~s}$.

${ }^{10}$ Patent na korisnu model' № 117078. Ukraina. MPK(2006.01) E02B 3/06. Sposib zvedennja beregozahisnoï sporudi / Rogachko S.I., Kazmiruk O.V., Slobodyanik G.V.; vinahidnik ta vlasnik Rogachko S.I., Kazmiruk O.V., Slobodyanik G.V.; № 201700702; Zajav.25.01.2017; Publ.12.06.2017, Bjul. № 11. 5 s. 


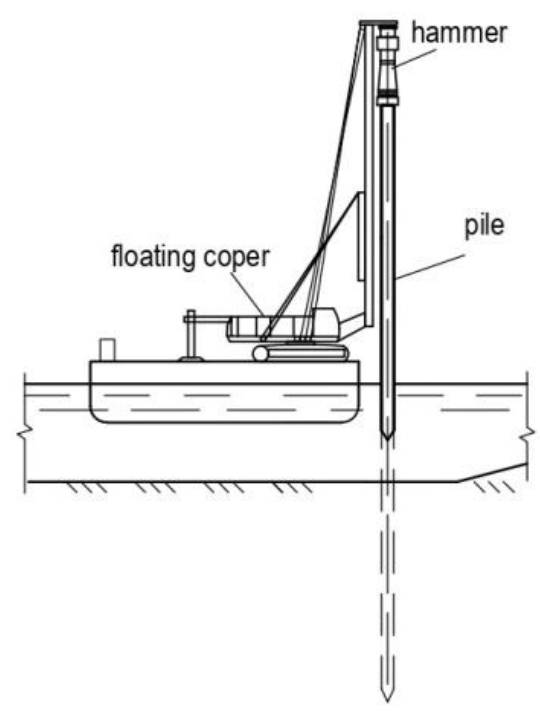

Fig. 5. Pile driving process

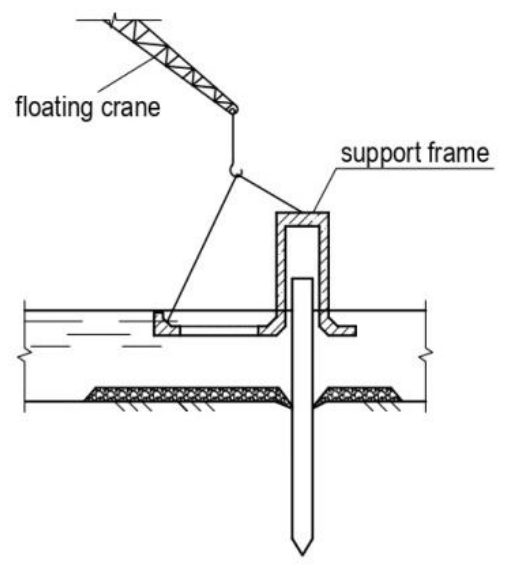

Fig. 7. Installation of the support

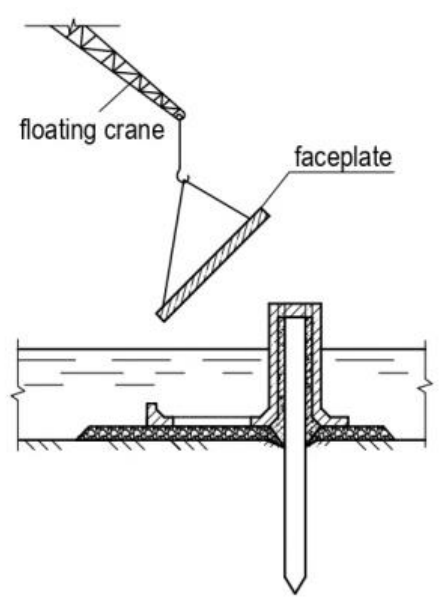

Fig.9. Installation of the faceplate

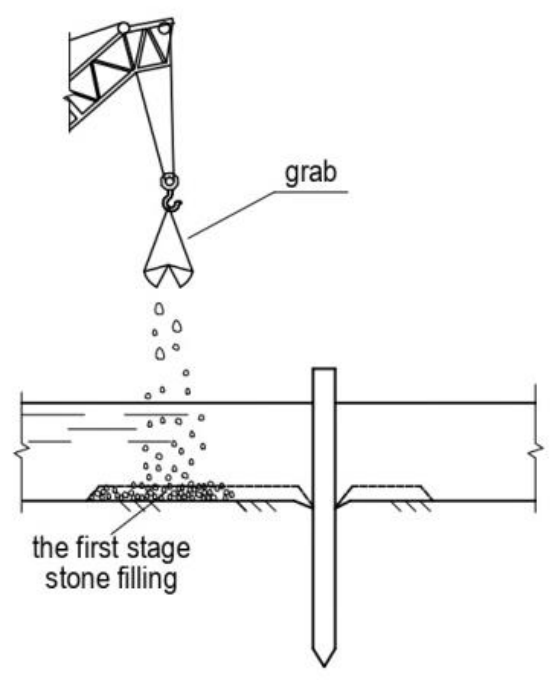

Fig. 6. Filling a stone in bed (the first stage)

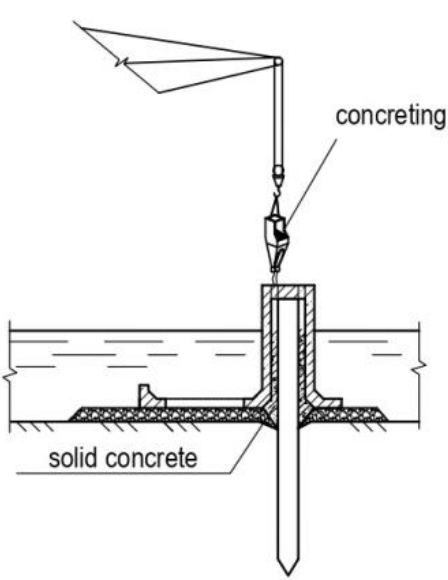

Fig. 8. Monolithic piles with frame in the design position

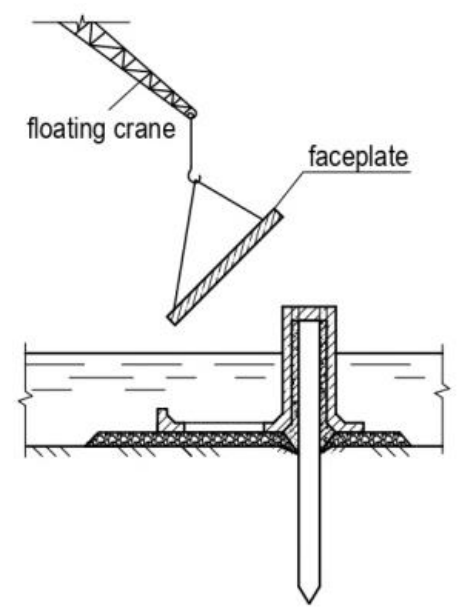

Fig. 10. Sand backfill 


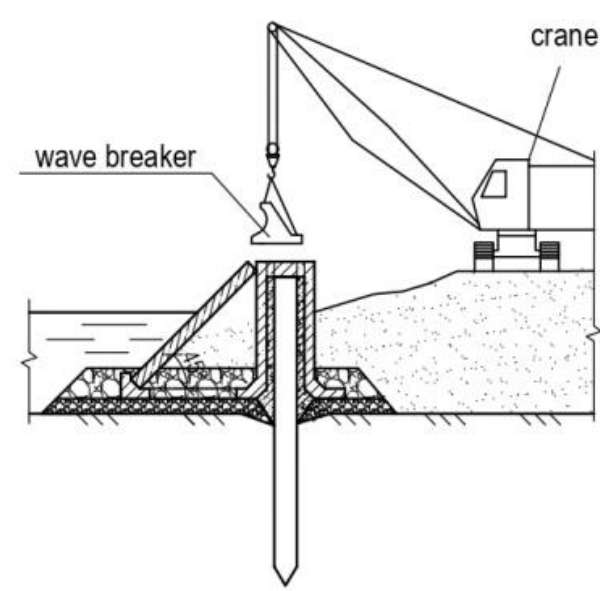

Fig. 11. Installation

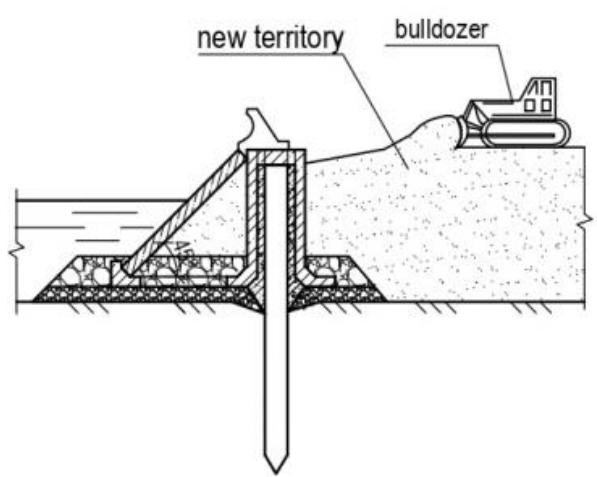

Fig. 12. Layout of an artificial territory of a wave breaker wall

The construction of this design does not require the production of a large amount of underwater technical work on the preparation of the foundation under the structure. This type of structure can be built on soils that allow pile driving. The shore protection structure is mounted from prefabricated unified elements, which allows us to increase the temps of construction. It can easily be recovered from local damage by severe storms or drifting ice formations. The construction is slightly sensitive to undermining of the base by currents and wave velocities.

\section{CONCLUSIONS}

1. The presented constructions can be used for: strengthening the coasts; the creation of additional territories in the coastal zones of the seas, lakes, reservoirs and estuaries; the creation of artificial islands for the development of offshore hydrocarbon deposits in the shallow areas of the continental shelf.

2. The developed method of building a universal hydraulic engineering structure in the open sea provides a reduction in construction time due to its simplicity.

3. The implementation of this method does not require a large amount of special underwater technical work on the preparation of the soil base under the construction.

4. The stone banquet before the construction simultaneously serves as a counter-filter and protects the soil base from erosion by currents and wave velocities.

5. The faceplates can be vertical, inclined or curved depending on the functional purpose and environmental conditions in the construction area.

6. The implementation of this method does not require the creation of a special production coastal base, since the structural elements of an innovative structure can be manufactured at factories of reinforced concrete structures. 
7. Constructive elements of the structure and rabble stone can be delivered to the construction site by water. Their loading on floating means should be carried out from the berths of the port fleet of the port closest to the construction site.

\section{SUMMARY}

The seashores of the Black Sea and the Azov Sea, estuaries, lakes and reservoirs in Ukraine are subject to intensive destruction by wind waves and drifting level ice. The onset of water on the coast leads to significant irretrievable losses of agricultural land and other material losses. For many decades, settlements located on the shores have lost entire streets along with houses built on them and other buildings. It is known, that there are cases of overburden of level ice under the influence of drift forces on gently sloping shores. In this case, all coastal structures located on them were destroyed. Such adverse events can only be avoided by building coastal protection structures capable of successfully resisting the force actions of these natural factors. The construction of shore protection structures is especially necessary in the locations of settlements and cities.

This article describes a new design of coast-protecting structures of mixed type to protect the coasts and create additional territories in the coastal zone of seas, lakes, reservoirs, estuaries and bays as well as artificial islands, for example, for the development of offshore hydrocarbon deposits. A phased technology for the construction of a shore protection structure is presented in accordance with the method developed by the authors of this article. The design of the universal shore protection structure and the method of its construction are protected by patents of Ukraine.

\section{REFERENCES}

1. Patent na korisnu model' № 113315. Ukraina. MPK (2006.01) E02B 3/04. Beregozahisna sporuda / Rogachko S. I., Slobodyanik G. V.; vinahidniki ta vlasniki Rogachko S.I., Slobodyanik G.V.; zajavl. 29.06.2016; opubl. 25.01.2017, Bjul. № 2. 4 s.

2. Patent na korisnu model' № 42602, Ukraina. MPK (2009) E02V 3/00. Universal'na beregozahisna sporuda / Rogachko S. I., Anisimov K. I, Sinicja R.V.; vlasnik Rogachko S.I. - u200901751; zajavl. 27.02.2009; opubl. 10.07.2009, Bjul. № 13. $6 \mathrm{~s}$.

3. Patent na vinahid № 92099, Ukraïna. MPK (2009) E02V 3/04, E02V 3/06. Universal'na beregozahisna sporuda / Rogachko S. I., Anisimov K. I., Sinicja R. V.; vlasnik Rogachko S. I. a200901752; zajavl. 27.02.2009; opubl. 27.09.2010, Bjul. № 18. 6 s. 
4. SNiP 2.06.04-82*. Nagruzki i vozdejstvija na gidrotehnicheskie sooruzhenija (volnovye, ledovye $\mathrm{i}$ ot sudov). Vzamen SNiP II-57-75: vved. 01-01-1984. M., 1995. $76 \mathrm{~s}$.

5. Ukazanija po raschetu nagruzok i vozdejstvij ot voln, sudov i l'da na morskie gidrotehnicheskie sooruzhenija. R 31.3.07-01, M., 2001. Dopolnenie i utochnenie SNiP 2.06.04-82* "Nagruzki i vozdejstvija na gidrotehnicheskie sooruzhenija (volnovye, ledovye i ot sudov), M., 1995, M., 2001. $77 \mathrm{s.}$

6. DBN V.1.1-12:2014 "Budivnictvo v sejsmichnih rajonah Ukraïni". K.: Minregionbud Ukraïni. Kiïv, 2014. 118 s.

7. DBN V.2.1-10:2018 “Osnovi i fundamenti budivel' ta sporud. Osnovni polozhennja". Vved. na zminu DBN V.2.1-10-2009; chinni vid 2019-01-01. Kyiv: Minregionbud Ukraïni, 2018. 36 s.

8. DBN V.2.6-98:2009 "Konstrukciï budinkiv i sporud. Betonni ta zalizobetonni konstrukciï. Osnovni polozhennja". K.: Minregionbud Ukraïni. Kyiv, 2011. $71 \mathrm{~s}$.

9. Patent na korisnu model' № 117078. Ukraïna. MPK (2006.01) E02B 3/06. Sposib zvedennja beregozahisnoï sporudi / Rogachko S. I., Kazmiruk O. V., Slobodyanik G. V.; vinahidnik ta vlasnik Rogachko S. I., Kazmiruk O. V., Slobodyanik G. V.; № 201700702; Zajav.25.01.2017; Publ.12.06.2017, Bjul. № 11. 5 s.

Information about the authors: Rogachko S. I., Doctor of Technical Sciences, Professor,

Department of Sea and River Ports, Waterways and Their Technical Maintenance, Odessa National Maritime University 34, Mechnikov str., Odessa, 65029, Ukraine ORCID ID: orcid.org/0000-0001-5201-5368

Slobodianyk H. V., $\mathrm{PhD}$, Candidate of Technical Sciences, Senior Lecturer at the Department of Sea and River Ports, Waterways and Their Technical Maintenance,

Odessa National Maritime University 34, Mechnikov str., Odessa, 65029, Ukraine ORCID ID: orcid.org/0000-0001-6437-0033 